\title{
Evaluating tropical forest classification and field sampling stratification from lidar to reduce effort and enable landscape monitoring
}

\author{
Daniel de Almeida Papa ${ }^{\mathrm{a}, *}$, Danilo Roberti Alves de Almeida ${ }^{\mathrm{b}}$, Carlos Alberto Silva ${ }^{\mathrm{c}}$, \\ Evandro Orfanó Figueiredo ${ }^{\mathrm{a}}$, Scott C. Stark ${ }^{\mathrm{d}}$, Ruben Valbuena ${ }^{\mathrm{e}}$, Luiz Carlos Estraviz Rodriguez ${ }^{\mathrm{b}}$, \\ Marcus Vinício Neves d' Oliveira ${ }^{\mathrm{a}}$ \\ ${ }^{a}$ Embrapa, Rio Branco, Acre, Brazil \\ ${ }^{\mathrm{b}}$ ESALQ-USP, São Paulo, Brazil \\ ${ }^{\mathrm{c}}$ University of Maryland, Geographical Sciences Department, USA \\ ${ }^{\mathrm{d}}$ Michigan State University, East Lansing, MI, USA \\ e Bangor University, School of Natural Sciences, United Kingdom
}

\section{A R T I C L E I N F O}

\section{Keywords:}

Forest management

Amazon

Airborne laser scanner

Leaf area density

Leaf area index

Cluster analysis

\begin{abstract}
A B S T R A C T
In high biodiversity areas, such as the Amazon, forest inventory is a challenge due to large variations in vegetation structure and inaccessibility. Capturing the full gradient of variability requires the acquisition of a large number of sample plots. Pre-stratified inventory is an efficient strategy that reduces sampling effort and cost. Low-cost remote sensing techniques may significantly expand pre-stratification capacity; however, the simplest option, satellite optical imagery, cannot detect small variations in primary forests. Alternatively, three-dimensional information obtained from airborne laser scanning (ALS, a.k.a. airborne lidar) has been successfully used to estimate structural parameters in tropical forests. Our objective was to assess to what extent forest plot sampling effort could be reduced, while accurately estimating mean vegetation characteristics in the landscape, by stratifying with ALS structural properties, relative to a random, uniformed conventional approach. The study was developed in an 800-ha area of wet Amazonian forest (Acre, Brazil), including portions of palms, bamboo and dense forest. We estimated relevant structural attributes from ALS: canopy height, openness, rugosity and fractions of leaf area index (LAI) along the vertical profile. We clustered vegetation to define heterogeneity into structural types, employing the Ward method and Euclidean distance. Also, principal component analysis was employed to characterize the groups using field and ALS-derived structural attributes. We simulated sampling intensities to estimate the gain in reducing the field efforts based on pre-stratified and non-stratified forest inventory scenarios. The resulting stratification clearly distinguished the forest's structural variation gradient and the vegetation density profile. For a fixed uncertainty of $10 \%$ in basal area estimation, the ALS-aided stratified inventory reduced the necessary number of field plots by $41 \%$, relative to simple random sampling. The resulting reduction in sampling effort can offset the cost of ALS data collection, significantly enhancing its financial feasibility. In addition, ALS provides broad-coverage quantifications of basal area (or aboveground carbon stock), canopy structure, and accurate terrain characterization, which have an added value for forest management.
\end{abstract}

\section{Introduction}

Forest inventories obtain estimates of fundamental variables including basal area, volume, and aboveground woody biomass based on population sampling methods (Næsset et al., 2013). Reliable forest estimates can be key to diagnosing conservation needs and potential for the sustainable use of resources (Bustamante et al., 2016). Due to the high structural variation of tropical rainforests, such as in the Amazon, sample inventories require great efforts to accurately quantify fundamental forest variables and their variation at landscape scales ( $\mathrm{Lu}$ et al., 2003).

Simple random sampling is typically used in small areas with minor variations in terrain and vegetation (Cochran, 1977). Other sampling methods may be adopted depending on the objectives of the inventory, conditions to access the forest, topography, hydrography, forest typology and the size of the area to be inventoried (Kangas and Maltamo,

\footnotetext{
* Corresponding author.

E-mail address: daniel.papa@embrapa.br (D.d.A. Papa).
} 
2006). In private forestry schemes and public forest concessions the management areas are large (thousands of hectares), with variations in the tree community as well as topographic and hydrographic conditions, which makes them difficult and expensive to characterize using a limited number of samples. Inappropriate or suboptimal choices in sampling method, or insufficient intensity and spatial coverage of field plots can generate biases or uncertainties in the estimation of the forest parameters (Moerman and Estabrook, 2006; Junttila et al., 2013; Marvin et al., 2014; Mauro et al., 2016). One option that may improve the accuracy of an inventory is to increase sampling intensity. However, in some cases this may be infeasible due to unaffordable costs and logistics. It is also challenging to evaluate the sampling intensity required to achieve a given target accuracy. The best alternative is to rely on detailed prior information of forest structural heterogeneity to adaptively optimize the sampling effort, with the intention of balancing the accuracy with the associated costs. This approach captures the maximum environmental variation using a minimum sampling effort (Maltamo et al., 2011; Niemi and Vauhkonen, 2016).

Stratified sampling consists of a subdivision of the forest into homogeneous groups prior to carrying out simple random sampling within each stratum (or forest-type group). This is known as pre-stratification, and it attains a variance within each stratum smaller than the total global variance of the whole population (Cochran, 1977; Tipton, 2013). It provides an opportunity for reducing sampling intensity, because part of the overall variance is explained by the strata. However, stratification of tropical forests is a major challenge due to their high complexity and density of vegetation (Asner et al., 2010; Alexander et al., 2017; Torresan et al., 2016). The combination of climatic environmental factors, topographic variation, edaphic characteristics, and forest dynamics represents a range of drivers with the potential to impact the diversity and variation of tropical forests (Clark and Clark, 1996; Condé and Tonini, 2013; Figueiredo et al., 2015; Nijland et al., 2015; Tang and Dubayah, 2017).

With the advent of orbital remote sensing, the variations of forest structure began to be classified and mapped with precision, especially those related to landscape macrostructures such as topographic variation and soil use (IBGE, 2012). However, passive orbital sensors have limited capacity to classify the ecologically significant variation of vegetation structure over the landscape (Lefsky et al., 2002; Asner et al., 2012; Ponzoni et al., 2012). In general, passive optical sensors are sensitive to changes in the biomass of young and homogeneous forests, with satisfactory efficiency in estimating biomass and leaf area index (LAI) for some biomes (Drake et al., 2002; Lefsky et al., 2002). However, in mature and heterogeneous rainforests, the spectral response is not sufficient to predict changes in biomass and volume, because vegetation indices saturate in areas with high LAI $\left(\sim 4 \mathrm{~m}^{2} \mathrm{~m}^{-2}\right)$ (Turner et al., 1999; McRoberts et al., 2017), and provide no information about the understory (Manzanera et al., 2016), causing uncertainty in forest typology differentiation (Lu, 2005; Ponzoni et al., 2012). Alternatively, airborne laser scanning (ALS, a.k.a. airborne lidar) stands out as an active remote sensor thanks to its ability to capture vegetation height information, and to penetrate vegetation vertical profiles, allowing the estimation of forest structural variation over forest landscapes with greater ecological, management, and carbon accounting relevance (Lefsky et al., 2002; Vastaranta, 2012; Junttila et al., 2013; Wulder et al., 2013; Manzanera et al., 2016).

An increasing number of studies have confirmed the use of ALS to estimate, model and characterize structural and ecological variables of forest cover, such as: tree identification and quantification of tree density (Yu et al., 2011; Gorgens et al., 2015; Ferraz et al., 2016; Silva et al., 2016), crown shape (Barnes et al., 2017; Figueiredo, 2014), LAI and vertical profile of vegetation (Stark et al., 2012; Detto et al., 2015; Almeida et al., 2016), carbon and biomass (D'Oliveira et al., 2012; Mascaro et al., 2011; Næsset and Gobakken, 2008; Silva et al., 2015, 2018), diameter distributions of the tree population (Maltamo et al., 2018), and demographic characterization of tree populations (Stark et al., 2015). ALS has also been successfully employed to stratify forest areas into structural types with shared characteristics (Jaskierniak et al., 2011; Valbuena et al., 2013, 2016, 2017; Niemi and Vauhkonen, 2016; Fedrigo et al., 2018), with some classifications validated across landscapes (Hansen et al., 2014; Moran et al., 2018; Adnan et al., 2019). For these reasons, ALS is being incorporated into the management and planning of forest activities in native and planted forest areas (Garabedian et al., 2017; Sanz et al., 2018; Almeida et al., 2019a). The potential of ALS to provide detailed structural characterization has been shown to offer advantages over field sampling, including plot allocation strategies according to the characteristics of each forest type (or forest stratum), or promoting cost reduction (Maltamo et al., 2011; Junttila et al., 2013; Dash et al., 2015; McRoberts et al., 2017). However, no prior studies of this kind have targeted structurally complex rainforests. Thus, there is a need to quantify the potential for adaptive forest sampling pre-stratification based on information on the distribution and extent of forest structural types offered by ALS remote sensing in Amazonian rainforests (Wulder et al., 2012).

Here we use ALS data to classify 800 ha of primary forest in western Amazonia according to variations in canopy structure. Then, we use the resulting classification to quantify the expected savings made in field sampling effort from an adaptive pre-stratified sampling strategy. This will allow us to balance the field effort essential to monitor larger areas of intact tropical forest.

\section{Materials and methods}

\subsection{Area of study}

The research was developed in the experimental forest of the Brazilian Agricultural Research Company (Embrapa), in the municipality of Rio Branco, Acre state, North-Western Brazil $\left(10^{\circ} 01^{\prime} 22^{\prime \prime} \mathrm{S}, 67^{\circ}\right.$ $40^{\prime} 3^{\prime \prime} \mathrm{W}$ ) (Fig. 1). The total area of the Embrapa Acre forest is 960 ha, 800 ha of which were included in the census. The hydrography is characterized by a vast drainage network derived from the Liberdade creek (Fig. 1e), which divides the property from the middle in a southto-north direction (Rodrigues et al., 2001). Terrain altitude above sea level ranges from 147 to $210 \mathrm{~m}$ (Fig. 1d). Topographic relief varies from planar to corrugated, and soils have high concentrations of low-permeability clays (Rodrigues et al., 2001). The climatic classification of the region, according to Koppen, is Aw, hot and humid equatorial (Alvares et al., 2013), with an annual average temperature of $24.3^{\circ} \mathrm{C}$ and an annual average rainfall of $1950 \mathrm{~mm}$ (Acre, 2010).

\subsection{Characterization of vegetation}

Previous studies in the area describe the occurrence of three main vegetation types: dense forest, secondary forest and open forest (D'Oliveira, 1994; Rodrigues et al., 2001). The dense forest type is characterized by an upper closed canopy of large trees, including species like the Brazil nut tree - Bertholletia excelsa (Bonpl.) -, Cumaru Dipteryx odorata (Aubl.), Wild -, and garapa - Apuleia leiocarpa (Vogel) JF Macbr -, which allows low light penetration, and thus vegetation density in the understory is sparse. In the secondary forest areas, the authors report vegetation of medium to large stature, with discontinuity in the canopy and indirect light penetration in the understory, in which palms, lianas and bamboos (Guadua weberbaueri Pilger) occupy separate forest vertical strata. Open areas are characterized by a greater vertical distance between dominant arboreal individuals and the dominant understory elements, bamboo and lianas, which are widespread and preclude the regeneration of trees and palms (south-central region of the area of study - Fig. 1g) (Rodrigues et al., 2001). Photos of vegetation can be seen in the supplementary material (Figs. S1-S13).

There are approximately 235 tree species from 65 different botanical families, with an average volume of $130 \mathrm{~m}^{3} \cdot \mathrm{ha}^{-1}$, an average tree density of 32 individuals $\mathrm{ha}^{-1}$, and an average basal area of $10 \mathrm{~m}^{2} \cdot \mathrm{ha}^{-1}$ 

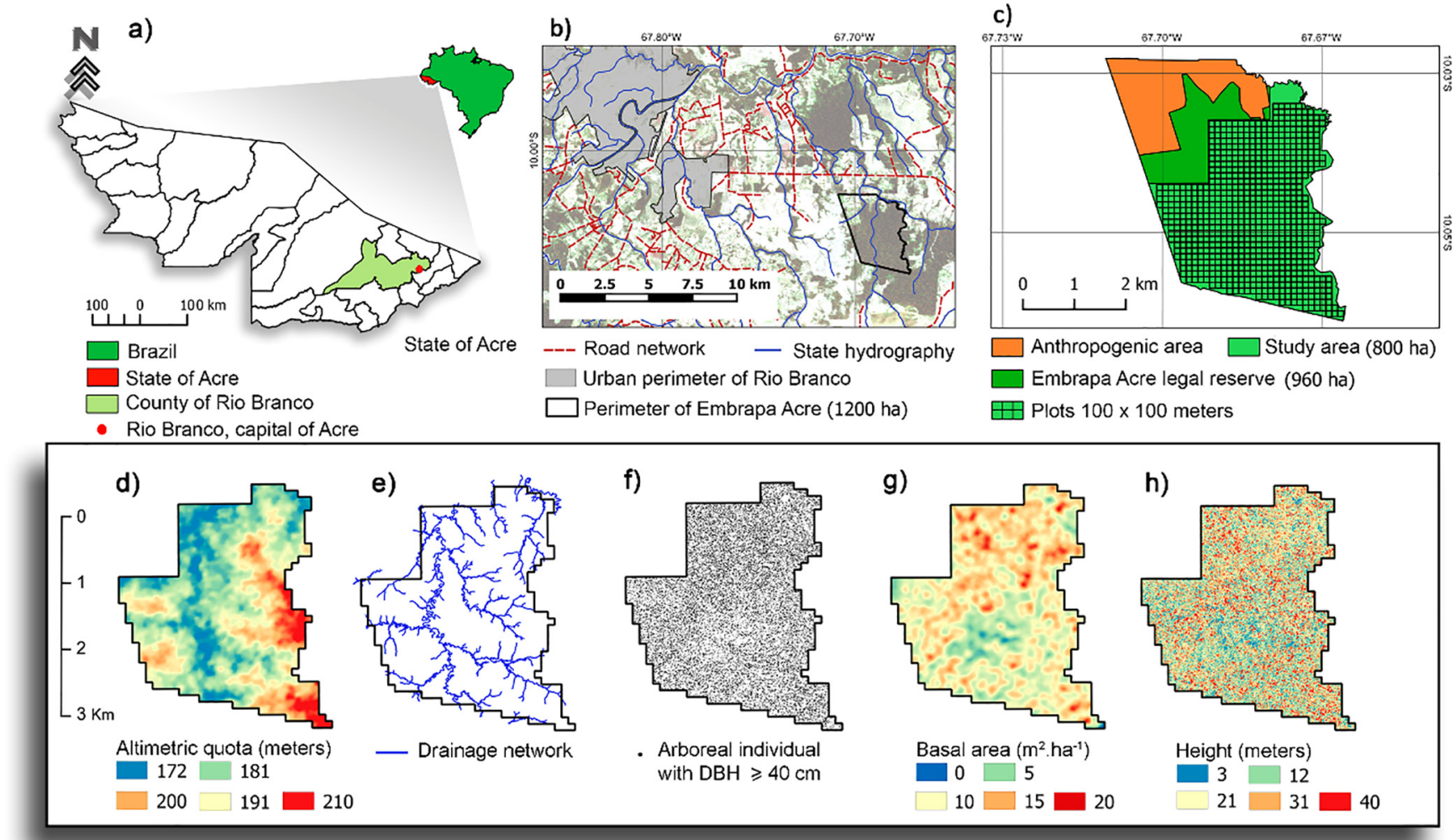

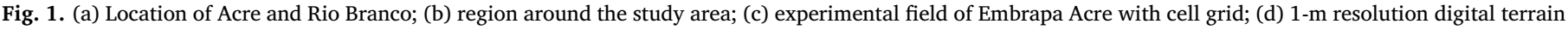

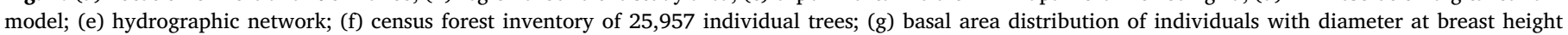
$\mathrm{DBH} \geq 40 \mathrm{~cm}$; (h) 2 -m resolution canopy height model (CHM).

- considering only individuals with DBH (diameter at breast height; $1.30 \mathrm{~m}$ ) $>40 \mathrm{~cm}$, see next section - (Fig. 1f). These studies corroborate the classification given by the Ecological Economic Zoning (EEZ) to the vegetation of the macro-region in the surroundings where the study area is located, which is of the open forest type, with palm, bamboo, and dense forest (Acre, 2010).

\subsection{Data collection}

Data collection was performed in two steps: field census forest inventory and ALS surveying. The field forest inventory was carried out on 800 ha between June 2014 and January 2015. The census collected the DBH of 22,957 woody plants (trees, palms, and lianas) with $\mathrm{DBH} \geq 40 \mathrm{~cm}$ (for multi-trunk individuals, each trunk was recorded). Each tree received a reference number plate and its location was georeferenced with a GNSS navigation receiver (Garmin $76 \mathrm{CSx}$ ). Basal areas were calculated as the sums of individual stems contained in the $100 \times 100 \mathrm{~m}$ sampling grid cells (Fig. 1c, g).

\subsection{ALS data collection}

The ALS flyover was conducted in 2015, shortly after the end of the field census. A CESSNA model 206 aircraft was used, equipped with Trimble's lidar Harrier 68i sensor. This ALS system was operated at $300 \mathrm{kHz}$, with a maximum scan angle of $\pm 11^{\circ}$ from nadir view, and a footprint diameter of $30 \mathrm{~cm}$. The average density of returns was $14 \mathrm{pts} \cdot \mathrm{m}^{-2}$ (Fig. S14). There were more than $4 \mathrm{pts} \cdot \mathrm{m}^{2}$ in $98.8 \%$ of the area, with an average aircraft speed of $200 \mathrm{~km} \cdot \mathrm{h}^{-1}$, a height of $600 \mathrm{~m}$, and a swath-width of approximately $490 \mathrm{~m}$.

\subsection{ALS data processing}

The ALS generated 169 million points, of which 37 million were classified as ground points via an interpolation algorithm using the linear prediction method SCOP (Trimble and Geo, 2014). The Digital Terrain Model (DTM) was produced from the ground points (average density of $0.43 \mathrm{pts} \cdot \mathrm{m}^{2}$ ) with $1-\mathrm{m}$ spatial resolution, using an inverse distance-weighted nearest neighbor interpolation method, as implemented in the package "lidR" (Roussel and Auty, 2018) in R environment (R Core Team, 2017). We then calculated the heights above ground by subtracting the elevation of the DTM from the height of each ALS point (Roussel and Auty, 2018). Spurious values, e.g. negative height returns and artifacts not representing the vegetation, were eliminated using a filtering algorithm. A $50 \times 50 \mathrm{~m}$ moving window was used to eliminate the upper outliers (returns with values greater than the third quartile plus 1.5 times the interquartile range), and also maximum returns $0.5 \mathrm{~m}$ higher than the fifth highest return.

The canopy height model (CHM) was calculated from the highest points of the normalized cloud within 2-m grid cells. The CHM was used to generate the following structural attributes of the canopy, at the 1-ha spatial resolution of the field plots (Almeida et al., 2019b): (i) canopy height (average of CHM); (ii) rugosity (standard deviation of $\mathrm{CHM}$ ); and (iii) canopy openness (fraction of CHM cells lower than a 15-m height threshold). The height threshold was selected to define gaps and other openings because closure in tropical forests usually occurs below $15 \mathrm{~m}$ in height (Asner et al., 2012), and for consistency with other work in the region (Almeida et al., 2016).

The number of ALS returns in the forest height gradient was also used to determine leaf area density (LAD) and leaf area index (LAI) metrics. From the cloud of ALS points within each horizontal cell, threedimensional (voxel) cells were created with horizontal ( $\mathrm{x}$ and $\mathrm{y}$ ) resolution of $2 \mathrm{~m}$ and vertical resolution ( $\mathrm{z}$ ) of $1 \mathrm{~m}$. In these cells we estimated the volumetric variation in leaf area density (LAD) of the vegetation, using the equation of MacArthur and Horn (1969) (Stark et al., 2012; Almeida et al., 2016, 2019a,b). This method for estimating vegetation closure is based on calculating optical density as the ratio 
between the number of returns that arrive in a voxel and the number of returns that come out from it, which is then attributed to leaf area with a scaling constant. Two attributes associated with vegetation density were calculated: (iv) LAI (sum of LAD profile), and (v) LAD understory $_{\text {. }}$ (sum of LAD between 5 and $12 \mathrm{~m}$ above the ground). We excluded LAD estimates below $5 \mathrm{~m}$, which were more uncertain because of limited pulse penetration low in the canopy and possible influence of ground returns (Stark et al., 2012; Almeida et al., 2019b).

\subsection{Data analysis}

The data analysis consisted of five steps: (i) creation of two- and three-dimensional grid cells and associated estimation of structural attributes derived from the field inventory and the ALS return cloud; (ii) the correlation of canopy attributes (ALS-derived) and field inventory basal area attribute; (iii) cluster analysis for formation of strata (forest structural types); (iv) validation and characterization of forest structural types; and finally, (v) estimation of reduction of the sampling effort. The steps are described below in more detail.

The study area was divided into 723 cells sizing $100 \times 100 \mathrm{~m}$ ( 1 ha), 1504 cells sizing $70 \times 70 \mathrm{~m}$ ( $0.5 \mathrm{ha})$, and 3013 cells sizing $50 \times 50 \mathrm{~m}(0.25 \mathrm{ha})$. For each cell, the field attribute (basal area) and the structural attributes of the forest canopy from ALS (described in the previous section) were calculated. Subsequently, a Pearson correlation analysis was carried out to select the best canopy structural attribute to utilize as a basis for the cluster analysis. To maximize our capacity to group cells with a single variable, we performed a hierarchical cluster analysis using Euclidean distance and Ward clustering method and by dist() and hclust() functions of "stats" R package (R Core Team, 2018). The cluster analysis creates forest-type groups that were later used for sub-sampling the field census via pre-stratification. The number of groups was established by the Elbow method (Tipton, 2013), which define the appropriate number of groups $(k)$ from a scree plot which depicts the variation in the total sum of residuals for an increasing number of clusters. The consistency of the groups was verified by the scree plot and dendrogram (Fig. 2). Also, the defined groups were validated with an ANOVA posthoc Tukey test (R Core Team, 2018), with group id as predictor and basal area as response variables. Groups were characterized with Principal Component Analysis (PCA) and Biplot graph (Kassambara and Mundt, 2017) of the ALS-derived structural attributes.

Finally, a computational simulation was done emulating forest inventory sampling. We compared a stratified sampling design against a completely randomized design with three different plot sizes: $1,0.5$ and 0.25 ha. Grid cells were subdivided according to these resolutions, and they were selected as if they were field plots. The stratified sampling was simulated by using weighting distributed by strata, so that each segment was the same sample size, whereas no weighting was used for the simulation in the case of the simple random sampling.

For each level of sampling size (number of plots in the inventory), 1000 iterations were performed, and their mean and standard deviation were summarized in order to produce a graph of relative uncertainty (standard error/global mean) as a function of sample intensity (proportion of total area sampled, in \%). In the computational simulation, the number of sample plots ranged from 10 to 60 for 1-ha plots; from 10 to 100 for 0.5 -ha plots; and from 10 to 140 for 0.25 -ha plots. Taking into account that the total area of our study site is 800 ha, a single sample plot with a size $1,0.5$ or 0.25 ha yields a sampling intensity of $0.125 \%, 0.0625 \%$ and $0.03125 \%$, respectively. Thus, the corresponding ranges in sampling intensities employed in each simulation were: $1.25-7.5 \%$ for 1 -ha plots; $0.63-6.25 \%$ for 0.5 -ha plots; and $0.39-4.38 \%$ for 0.25 -ha plots.

Inventories by stratified sampling were compared against simple random sampling for the three plot sizes and over the range of segment numbers. The cut-off limit established for comparison between stratified and simple random sampling designs was a $10 \%$ of relative uncertainty, which is the admissible sampling error limit in inventories for forest management plans (Brasil, 2007). The notations and the stratified inventory estimators are presented below (Cochran, 1977). The suffix $h$ denotes the stratum, and $i$ the sampling unit within each stratum.

Stratum-wise mean estimator of variable $y$ (e.g., basal area in $\left.\mathrm{m}^{2} \cdot \mathrm{ha}^{-1}\right)$

$\widehat{\mu}_{h}=\frac{1}{n_{h}} \sum_{i=1}^{n_{h}} y_{h i}$

Global mean estimator of variable $y$

$\widehat{\mu}=\sum_{h=1}^{H} W_{h} \widehat{\mu}_{h}$

Stratum-wise variance estimator of variable $y$

$\hat{\sigma}^{2}{ }_{h}=\frac{1}{n_{h}-1} \sum_{i=1}^{n_{h}}\left(y_{h i}-\hat{\mu}_{h}\right)^{2}$

Global variance estimator of variable $y$;

$\operatorname{Vâ} r\left(\hat{\mu}_{S t r}\right)=\sum_{h=1}^{H} W_{h}^{2} \frac{\hat{\sigma}^{2} h}{n_{h}}$

Standard error of the global mean of variable $y$

$E\left(\hat{\mu}_{S t r}\right)=\sqrt{\operatorname{Va} r\left(\hat{\mu}_{S t r}\right)}$

$n_{h}=$ number of plots in the stratum; $N=$ total number of plots;
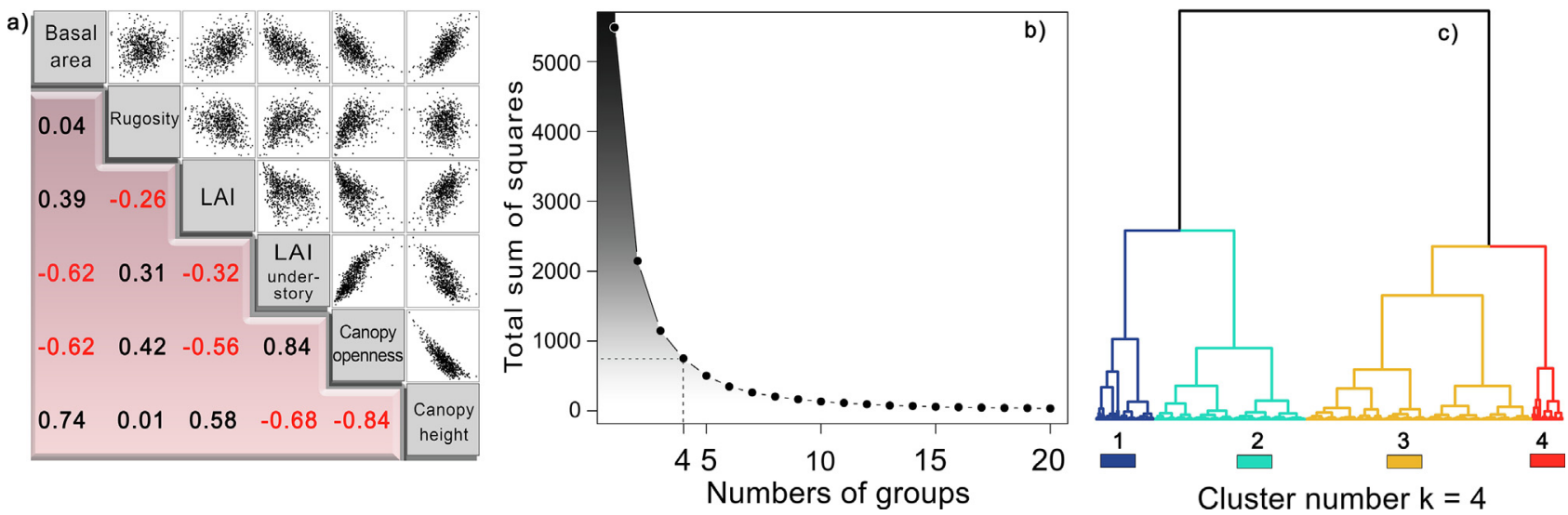

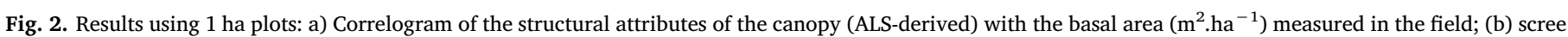

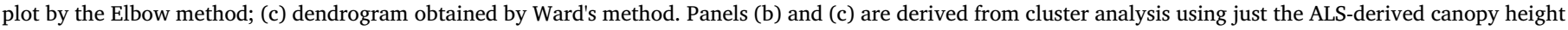
attribute. 
Table 1

Statistical summary of vegetation attributes for the four segments.

\begin{tabular}{|c|c|c|c|c|c|c|c|c|}
\hline \multirow[t]{2}{*}{ Field and Lidar variables } & \multicolumn{2}{|c|}{ Group 01} & \multicolumn{2}{|c|}{ Group 02} & \multicolumn{2}{|c|}{ Group 03} & \multicolumn{2}{|c|}{ Group 4} \\
\hline & Mean & Standard deviation & Mean & Standard deviation & Mean & Standard deviation & Mean & Standard deviation \\
\hline Basal area $\left(\mathrm{m}^{2} \cdot \mathrm{ha}^{-1}\right)$ & 5.92 & 2.03 & 8.97 & 2.28 & 11.26 & 2.29 & 14.58 & 2.7 \\
\hline Canopy height (m) & 19.2 & 1.54 & 22.52 & 0.78 & 25.48 & 1.09 & 29.24 & 1.24 \\
\hline Rugosity (m) & 8.68 & 1.19 & 8.86 & 1.13 & 8.83 & 1.22 & 8.87 & 1.17 \\
\hline LAI $\left(\mathrm{m}^{2} \cdot \mathrm{m}^{-2}\right)$ & 1.72 & 0.32 & 1.97 & 0.03 & 2.21 & 0.28 & 2.43 & 0.27 \\
\hline LAI_undersoty $\left(\mathrm{m}^{2} \cdot \mathrm{m}^{-2}\right)$ & 0.57 & 0.09 & 0.44 & 0.1 & 0.35 & 0.1 & 0.28 & 0.07 \\
\hline Canopy openness (\%) & 0.35 & 0.08 & 0.22 & 0.06 & 0.14 & 0.05 & 0.08 & 0.04 \\
\hline
\end{tabular}

$H=$ total number of strata; $y_{h i}=$ value obtained for $i$ plot at stratum $h$; $W_{h}=$ weight of stratum $h\left(n_{h} / N\right)$.

\section{Results}

We selected Canopy Height as our structural variable for forest stratification because it was the canopy structure variable that showed the highest correlation with the basal field area (Fig. 2a). Using the Elbow method (Fig. 2b), the optimal number of groups adopted was $k=4$, as can be observed in the dendrogram (Fig. 2c). The values of average and standard deviation of the variables obtained for $100 \times 100$ cells are described in Table 1 . Note that the average basal area and the average canopy height increase steadily from stratum 01 to 04 (Table 1 and Fig. 3a).

To corroborate the relevance of this classification from the viewpoint of the field information, an ANOVA posthoc Tukey's test was performed, which resulted in a significant difference of $5 \%$ for the average basal area among all segments (Fig. 3b). The map (Fig. 3c) shows the spatial distribution of the four groups throughout the study area. Analyzing the first component (Z1) from the PCA, the variables canopy openness (eigenvector $=0.55$ ), canopy height (eigenvector $=-0.50$ ), LAI $_{\text {understory }}$ (eigenvector $=0.48$ ), and LAI (eigenvector $=-0.39$ ) together represented most of the structural variation in the forest. This gradient of structural variation can be observed from both the vegetation profiles of the four strata separately (Fig. 4b), and also from thee variations in the forest canopy observed from the CHM and the ALS data (Fig. 4c and d). The low weight of the variable rugosity (eigenvector $=0.23$ ) in the first component shows that this variable had little impact on the characterization of groups.

The sample intensity reduction was calculated for each of the three plot sizes, with different classes of stratification and relative uncertainty set at $10 \%$ (Table 2). It was not possible to calculate average and standard deviation in the simulated inventory for $k=6$ and 7 for the spatial resolution of 1 and 0.5 ha, because the number of plots in one of the strata was $N=1$. The computational simulation (Fig. 5) illustrates the estimated difference between stratified and simple random sampling for the three plot sizes analyzed.

\section{Discussion}

To our knowledge, this is the first paper to analyze the potential of ALS technology to reduce field sampling intensity in Amazonian forest inventories. In general, ALS was able to generate strata that differentiated variation in forest basal area, reducing the sample effort by up to $41 \%$. In this study we focused on basal area because it is a direct field measurement. Nevertheless, other parameters of interest that can be estimated by using allometric equations, such as volume and aboveground woody dry biomass, would also be more efficiently sampled taking our forest ALS survey-based stratification approach (Supplementary Fig. S15).

To implement this approach it is necessary to have a means to define an efficient number of strata. As in previous similar studies like that of Adnan et al. (2019), the Elbow criterion proved to be an efficient approach to determine the number of segments $(k=4)$, as demonstrated by significant differentiation of basal area. However, the stratification potential for estimating basal area from the ALS canopy height metric was even greater, since in the present study, up to six segments $(k=6)$ were discriminated with significant differences. Therefore, there is no need to rigorously adopt the Elbow criterion, although it is a good indicator to determine the optimal number of groups. On the other hand, the choice of additional strata beyond approximately $k=6$ generated little additional gain in the estimates (Table 2) and may even be inefficient by partitioning the population into groups comprising a small number of potential sample plot locations, increasing the variance of the estimates (McRoberts et al., 2012; Mauro et al., 2016) or even making it impossible to calculate the stratum-weighted sampling. As an example, Table 2 shows the decrease in the sampling intensity when increasing group number from 6 to 7 in plots of 0.25 ha.

The correlation between the canopy height and basal area at plot level can be explained by the ALS's sensitivity in capturing the height of dominant and co-dominant trees occupying the forest canopy and which are positively related to stem diameter and basal area (Asner
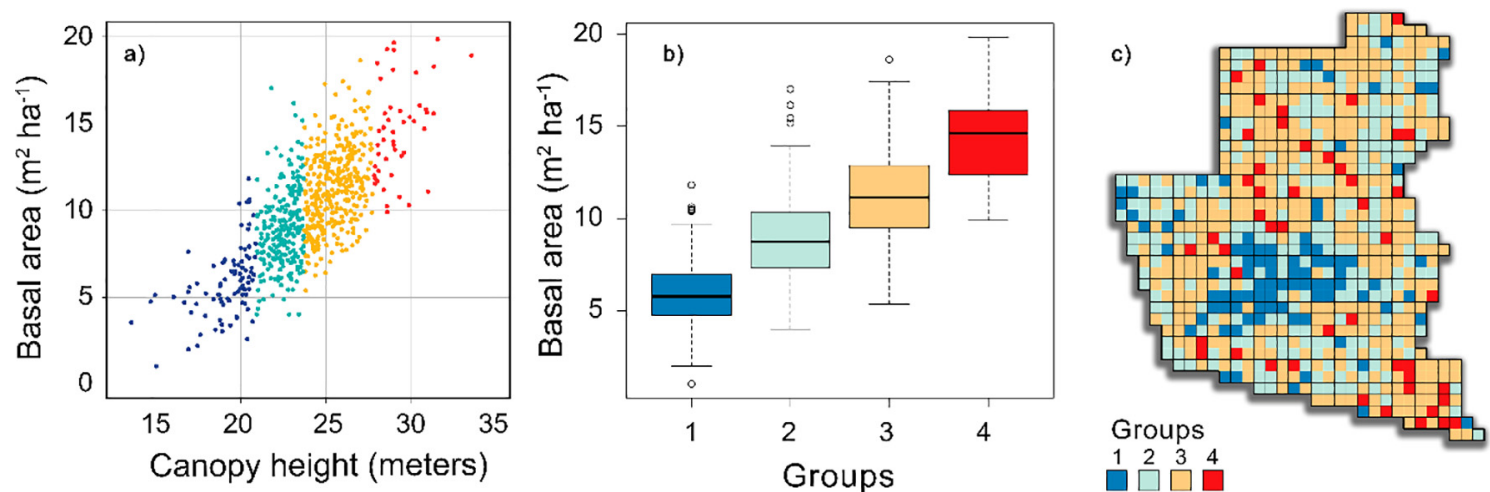

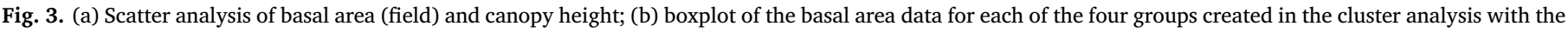
canopy height; (c) map of cells classified by stratum. 


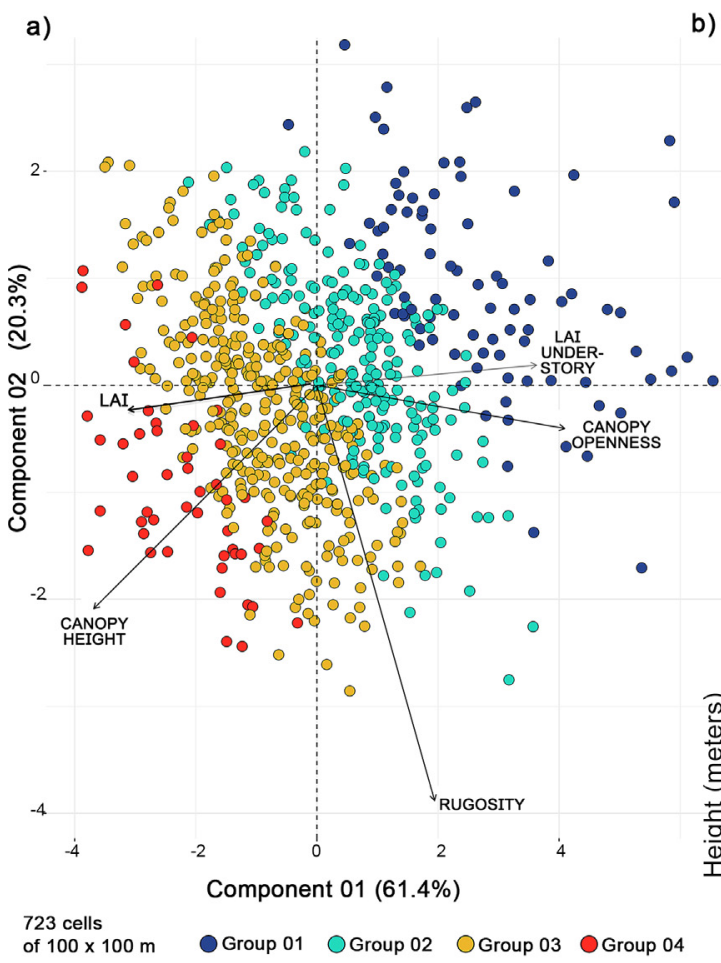

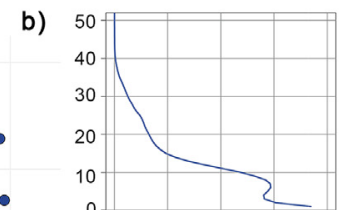
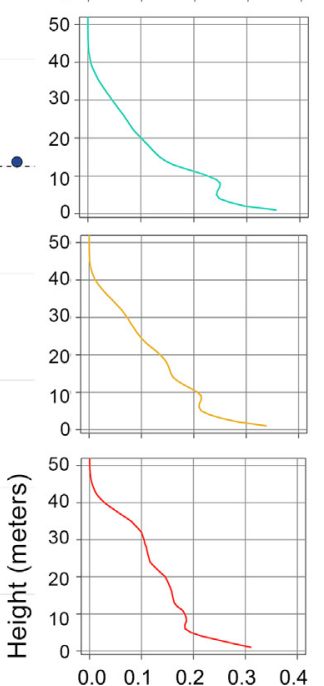

Leaf area density $\left(\mathrm{m}^{2} \mathrm{~m}^{-3}\right)$ c)
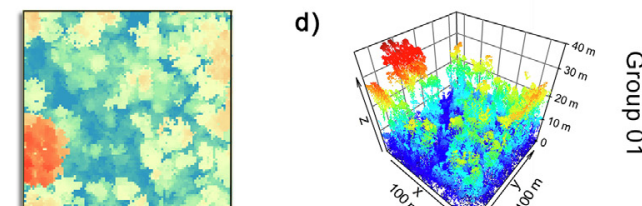

๑
$\stackrel{\circ}{\circ}$
$\stackrel{0}{\circ}$

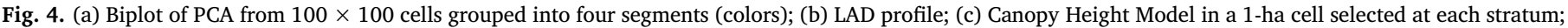

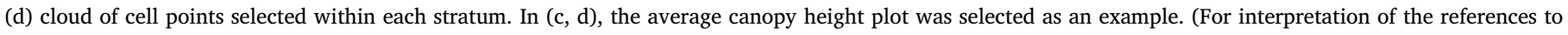
colour in this figure legend, the reader is referred to the web version of this article.)

et al., 2002, 2012; Baker and Wilson, 2000; Sullivan et al., 2017). However, allometric relationships between tree size and shape may vary from forest to forest, or even from tree to tree (Lefsky et al., 1999a,b; Mäkelä and Valentine, 2006; Dahle and Grabosky, 2009). Therefore, the use of a single ALS variable will not always be efficient in distinguishing forest typologies and parameters (biomass, basal area), since a forest with a more homogeneous structure and little variation in canopy height may generate a low correlation between ALS and field data (Baker and Wilson, 2000; Kennel et al., 2013; Palace et al., 2015).

In our study, the use of the canopy height for stratification was also efficient in ordering other structural parameters of the canopy (Fig. 4a). Forests with lower height have greater canopy opening and, consequently, higher vegetation density of the understory (LAI understory $_{\text {). The }}$ canopy rugosity was relatively high $(\sim 9 \mathrm{~m})$ in all strata; therefore, it does not serve as a good stratification parameter in this case. This variation of canopy height can be explained by the nature of the forest type studied, which is predominantly open, scattered with clusters of dominant trees, clearings of different sizes and succession stages, and the occurrence of lianas and bamboo in areas with a higher incidence of light.

The use of ALS in the differentiation of forest patterns is associated with improved estimations, reduction of prediction errors, and optimization of the sampling effort. In a mixed forest with predominance of pine and deciduous species, Hawbaker et al. (2009) achieved a 68\% reduction in model prediction error for the variables diameter, basal area, and biomass when estimating them separately according to strata created with ALS data. In heterogeneous temperate forests, Heurich and Thoma (2008) obtained lower RMSE values for basal area and volume estimates $(\sim 15 \%)$ when estimating by stratified forest inventory using ALS, compared to non-stratified population estimates (30\%).

Besides the improvement in the estimates, the stratification allows the reduction in the number of plots needed to capture the forest variation gradient, which allows sampling intensity to be decreased. In a mixed forest of pine and deciduous trees, McRoberts, Chen and Walters

Table 2

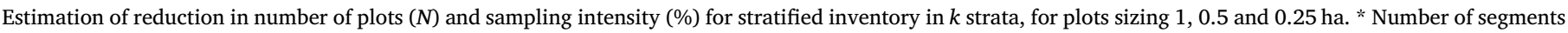
selected by the Elbow method. ** Number of segments with no significant difference in at least one pair of segments. NA: not available due to $N<2$.

\begin{tabular}{|c|c|c|c|c|c|c|c|c|c|c|c|c|c|}
\hline \multirow[t]{2}{*}{ Plot size } & \multirow[t]{2}{*}{ Simulation } & \multicolumn{2}{|l|}{$\mathrm{k} 2$} & \multicolumn{2}{|l|}{ k3 } & \multicolumn{2}{|c|}{$\mathrm{k} 4$ * } & \multicolumn{2}{|l|}{ k5 } & \multicolumn{2}{|l|}{ k6 } & \multicolumn{2}{|c|}{$\mathrm{k} 7 * *$} \\
\hline & & $\mathrm{N}$ & $\%$ & $\mathrm{~N}$ & $\%$ & $\mathrm{~N}$ & $\%$ & $\mathrm{~N}$ & $\%$ & $\mathrm{~N}$ & $\%$ & $\mathrm{~N}$ & $\%$ \\
\hline \multirow[t]{3}{*}{$100 \times 100 \mathrm{~m}(1 \mathrm{ha})$} & Stratified & 34 & 4.7 & 30 & 4.1 & 27 & 3.7 & 25 & 3.5 & \multirow[t]{3}{*}{$\underline{\mathrm{NA}}$} & & \multirow[t]{3}{*}{$\underline{\mathrm{NA}}$} & \\
\hline & Randon & 46 & 6.4 & 46 & 6.4 & 46 & 6.4 & 46 & 6.4 & & & & \\
\hline & REDUCTION & $26 \%$ & & $35 \%$ & & $41 \%$ & & $46 \%$ & & & & & \\
\hline \multirow[t]{3}{*}{$70 \times 70 \mathrm{~m}(0.5 \mathrm{ha})$} & Stratified & 53 & 3.5 & 45 & 3.0 & 44 & 2.9 & 42 & 2.8 & \multirow[t]{3}{*}{$\underline{\mathrm{NA}}$} & & \multirow[t]{3}{*}{$\underline{\mathrm{NA}}$} & \\
\hline & Randon & 76 & 5.1 & 76 & 5.1 & 76 & 5.1 & 76 & 5.1 & & & & \\
\hline & REDUCTION & $30 \%$ & & $41 \%$ & & $42 \%$ & & $45 \%$ & & & & & \\
\hline \multirow[t]{3}{*}{$50 \times 50 \mathrm{~m}(0.25 \mathrm{ha})$} & Stratified & 89 & 3.0 & 80 & 2.7 & 75 & 2.5 & 69 & 2.3 & 67 & 2.2 & 67 & 2.2 \\
\hline & Randon & 112 & 4.0 & 121 & 4.0 & 122 & 4.0 & 121 & 4.0 & 120 & 4.0 & 119 & 3.9 \\
\hline & REDUCTION & $27 \%$ & & \multicolumn{2}{|c|}{$33.90 \%$} & \multicolumn{2}{|c|}{$38.50 \%$} & \multicolumn{2}{|l|}{$43 \%$} & \multicolumn{2}{|c|}{$44.20 \%$} & \multicolumn{2}{|c|}{$43.70 \%$} \\
\hline
\end{tabular}



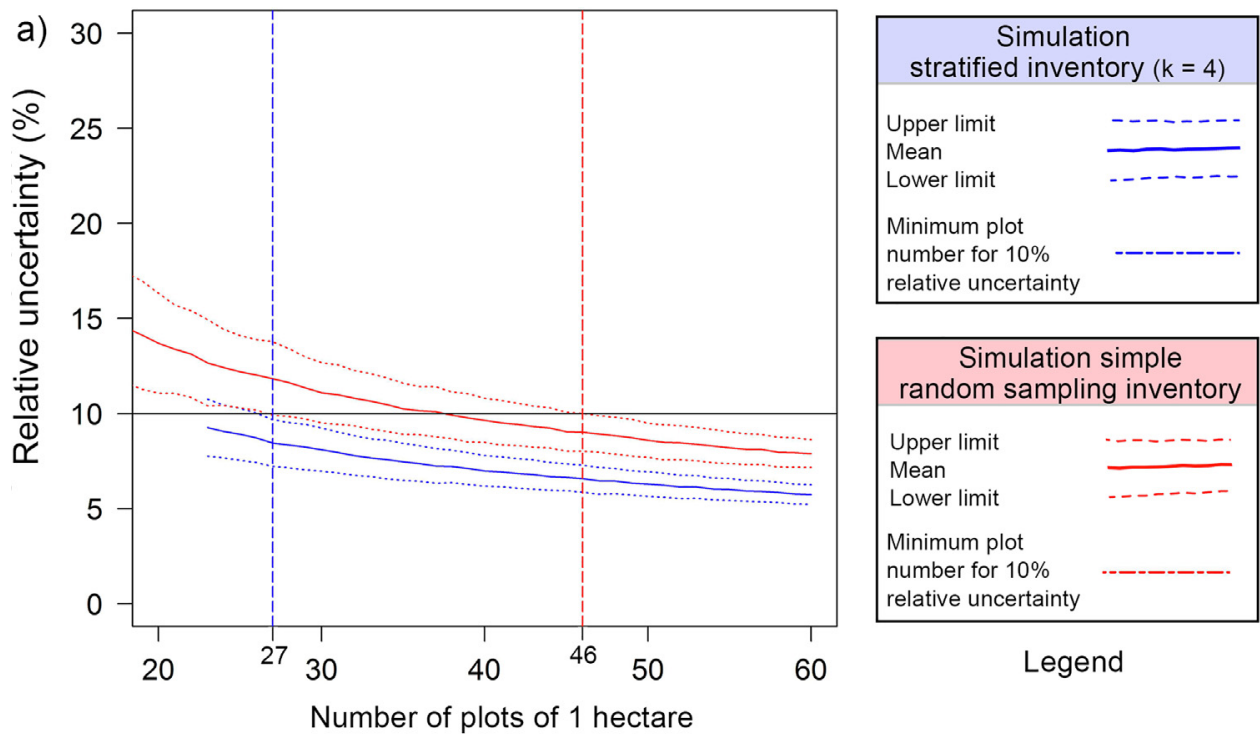

Legend
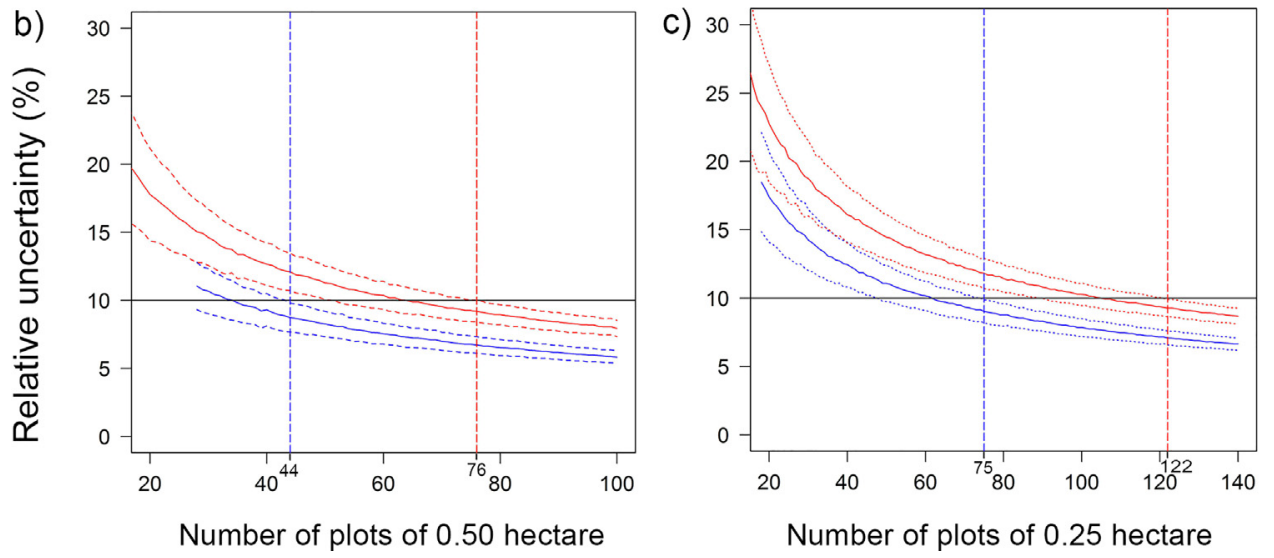

Fig. 5. Computational simulation of stratified inventory in four segments $(k=4)$ (blue) versus completely randomized (red) for three sizes of plots: (a) $100 \times 100 \mathrm{~m}$; (b) $70 \times 70 \mathrm{~m}$; and (c) $50 \times 50 \mathrm{~m}$. The upper and lower confidence limits were set for alpha $=0.05$.

(2017) were able to reduce sampling intensity by up to $35 \%$ without losing accuracy in the estimators, based on stratification with canopy height metrics obtained from ALS. In the present study, there was a reduction of the sample intensity because the population was grouped in a larger number of strata (up to $k=6$ ), varying from 26 to $46 \%$ of relative gains.

As for the size of the plots, we found that the reduction in sampling intensity for the stratified inventory was higher for 0.5-ha plots, with the exception of $k=5$. However, in terms of area, plots of 1-ha had a higher gain (3.7\% or 19 ha) when compared to the other two plot sizes: 0.5 ha $(2.9 \%$ or 16 ha) and 0.25 ha $(2.5 \%$ or 12 ha). Another advantage of the 1-ha plot is that it better captures the gradient of vegetation variation with a lower number of field samples.

The benefits of stratification include reduced effort and economic gains, because the amount of plot sampling for effective inventory and monitoring is reduced. McRoberts, Gobakken and Næsset (2012) compared the cost of ALS overflight to the cost of the field sampling and found that sample intensity needed to be increased by $50 \%$ to achieve the same reduction of the variance obtained from the ALS-enabled stratified inventory approach. The total costs were very similar, but the authors emphasize that the investment in the laser survey generates other benefits, such as the DTM. ALS also offers the capacity of ecological analysis of a variety of factors relevant to forest monitoring and management (Lefsky et al., 2002; Yu et al., 2011; Vastaranta, 2012; Ferraz et al., 2016; Silva et al., 2016). Analogously to McRoberts, Gobakken and Næsset (2012), we can discuss the expected reduction in cost that would result from our approach in the Acre Embrapa forest using approximate values obtained from consultation with specialized companies that provide ALS overflight services and forest inventory in the Amazon region. For purposes of example, with the costs of the ALS flight at US $\$ 33.00 \mathrm{ha}^{-1}$, and the costs of surveying forest inventory plots (including trees with $\mathrm{DBH} \geq 10 \mathrm{~cm}$ ) at US $\$ 1500.00 \mathrm{ha}^{-1}$, then we can calculate the expected cost of plot sampling with the savings made by reducing effort. Then, given the difference between the number of plots of the stratified inventory and the simple random sampling inventory was 19 plots of 1 ha, the saved costs reach approximately US $\$ 28,500.00$ for installation and measurement. This is $41 \%$ of the total cost of the estimated sampling without stratification (i.e., US $\$ 69,000.00$ ). This value of savings is slightly higher than the total cost of ALS, estimated at US \$26,400.00 for the total area overflown in this work.

In addition to the reduction of the sampling intensity resulting from the stratification, the information on vegetation structure provided by ALS has many advantages for the management of tropical forests. It offers the possibility of generating volumetric maps that can assist in the planning of harvest units, the identification of clearings and areas of low potential for timber, monitoring of volumetric growth and forest biomass after harvesting activities, and survey information that optimizes harvesting operations in the field, such as the modeling of terrain, watercourses and vegetation density in the understory. Since ALS can measure and estimate important structural attributes significant to forest management, it is a powerful tool for decision-making in 
management actions (Wulder et al., 2012), which may amplify its return on investment beyond efficiency gains from sampling stratification. Furthermore, NASA's Global Ecosystem Dynamics Investigation (GEDI), a recently operational spaceborne lidar system, is already on board the international space station and collecting 25-m diameter footprint measurements of canopy structure attributes. GEDI could thus be an alternative dataset for reducing field sampling efforts and landscape monitoring in tropical forests. This could be especially true if, by combining GEDI with other remote sensing data, such as Landsat or TanDEM-X InSAR data, spatially-continuous maps of canopy structural attributes can be derived at a similar spatial resolution to the one employed in our study (e.g. Qi et al., 2019).

\section{Conclusion}

The average height of the forest canopy, obtained by the ALS flyover, was a good predictor of the variation of basal area of trees with timber potential $(\mathrm{DBH} \geq 40 \mathrm{~cm})$ in open - type primary forests with palm, bamboo and dense forest portions. The remote airborne lidar sensor was efficient for planning the forest inventory, allowing for stratification of sampling effort to be equal across forest types (no matter their frequency on the landscape), reducing the number of sample units by $41 \%$, from 46 to 27 (1-ha plots with 4 strata, i.e, vegetation types). Stratification also offered a reduction of the sampling intensity in inventories with plots sizing 0.5 and 0.25 ha, but with smaller sampling area and greater number of field plots. The results of the use of ALS in areas of primary forest subject to forest management in the Amazon have great advantages, considering the high costs and efforts made to carry out a diagnostic inventory in the field. In addition, ALS generates strategic information for the planning of logging and conservation of the forest landscape.

\section{Acknowledgments}

D. Almeida was supported by the São Paulo Research Foundation (\#2018/21338-3 and \#2019/14697-0).

\section{Appendix A. Supplementary data}

Supplementary data to this article can be found online at https:// doi.org/10.1016/j.foreco.2019.117634.

\section{References}

Acre. Governo do estado do Acre, 2010. Zoneamento ecológico econômico do Acre: fase II - escala 1:250.000 - documento síntese. 2. ed. Rio Branco: SEMA Acre. (Coleção Temática do ZEE, v. 4).

Adnan, S., Maltamo, M., Coomes, D.A., García-Abril, A., Malhi, Y., Manzanera, J.A., Butt, N., Morecroft, M., Valbuena, R., 2019. A simple approach to forest structure classification using airborne laser scanning that can be adopted across bioregions. For. Ecol. Manage. 433, 111-121.

Alexander, C., Korstjens, A.H., Hill, R.A., 2017. Structural attributes of individual trees for identifying homogeneous patches in a tropical rainforest. Int. J. Appl. Earth Obs. Geoinf. 55, 68-72.

Almeida, D.R.A. de, Nelson, B.W., Schietti, J., Gorgens, E.B., Resende, A.F., Stark, S.C., Valbuena, R., 2016. Contrasting fire damage and fire susceptibility between seasonally flooded forest and upland forest in the Central Amazon using portable profiling LIDAR. Remote Sens. Environ. 184, 153-160.

Almeida, D.R.A., Mendes, A.F., Nelson, B.W., Görgens, E.B., Schietti, J., Duarte, M.M., Gonçalves, N.B., Amazonas, N.T., Meli, P., Brancalion, P.H.S., Chazdon, R., Valbuena, R., Stark, S.C., Moreno, V., 2019a. The effectiveness of Lidar remote sensing for monitoring tree cover attributes in forest and landscape restoration. For. Ecol. Manage. 438, 34-43.

Almeida, D.R.A., Stark, S.C., Shao, G., Schietti, J., Nelson, B.W., Silva, C.A., Görgens, E.B., Valbuena, R., Papa, D.A., Brancalion, P.H.S., 2019b. Optimizing the remote detection of tropical rainforest structure with airborne lidar: leaf area profile sensitivity to pulse density and spatial resolution. Remote Sens. 11 (1), 92-107.

Alvares, C.A., Stape, J.L., Sentelhas, P.C., Gonçalves, J.L. de M., Sparovek, G., 2013. Köppen's climate classification map for Brazil. Meteorol. Z. 22, 711-728.

Asner, G.P., Palace, M., Keller, M., Pereira Júnior, R., Silva, J.N.M., Zweede, J.C., 2002 Estimating canopy structure in an Amazon Forest from laser range finder and IKONOS satellite observations. Biotropica 34 (4), 483-492.
Asner, G.P., Powell, G.V.N., Mascaro, J., Knapp, D.E., Clark, J.K., Jacobson, J., KennedyBowdoin, T., Balaji, A., Paez-Acosta, G., Victoria, E., Secada, L., Valqui, M., Hughes, F., 2010. High-resolution forest carbon stock and emissions in the Amazon. Proc. Natl. Acad. Sci. U.S.A. 107 (38).

Asner, G.P., Mascaro, J., Muller-Landau, H.C., Vieilledent, G., Vaudry, R., Rosamoelina, M., Hall, J.S., Van Breugel, M., 2012. A universal airborne LiDAR approach for tropical forest carbon mapping. Oecologia 168, 1147-1160.

Baker, P.J., Wilson, J.S.A., 2000. A quantitative technique for the identification of canopy stratification in tropical and temperate forests. For. Ecol. Manage. 127, 77-86.

Barnes, C., Balzter, H., Barrett, K., Eddy, J., Milner, S., Suárez, J.C., 2017. Airborne laser scanning and tree crown fragmentation metrics for the assessment of Phytophthora ramorum infected larch forest stands. For. Ecol. Manage. 404, 294-305.

Bustamante, M.M., Roitman, I., Aide, T.M., Alencar, A., Anderson, L.O., Aragão, L., Asner, G.P., Barlow, J., Berenguer, E., Chambers, J., Costa, M.H., Fanin, T., Ferreira, L.G., Ferreira, J., Keller, M., Magnusson, W.E., Morales-Barquero, L., Morton, D., Ometto, J.P., Palace, M., Peres, C.A., Silvério, D., Trumbore, S., Vieira, I.C., 2016. Toward an integrated monitoring framework to assess the effects of tropical forest degradation and recovery on carbon stocks and biodiversity. Glob. Change Biol. 22, 92-109.

Brasil, 2007. Norma de Execução n ${ }^{\circ}$ 1, de 24 de abril de 2007. Altera as normas técnicas para o manejo florestal na Amazônia. Diário Oficial da República Federativa do Brasil, Brasília, DF, n. 83, Seção 1. p. 9.

Clark, D.B., Clark, D.A., 1996. Abundance, growth and mortality of very large trees in neotropical lowland rain forest. For. Ecol. Manage. 80, 235-244.

Cochran, W.G., 1977. Sampling Techniques, third ed. Wiley, New York.

Condé, T.M., Tonini, H., 2013. Fitossociologia de uma floresta ombrófila densa na Amazônia Setentrional, Roraima, Brasil. Acta Amazonica 43 (3), 247-260.

D’Oliveira, M.V.N., 1994. Composição florística e potenciais madeireiro e extrativista em uma área de floresta no Estado do Acre. Rio Branco: EMBRAPA-CPAF-Acre. (Série EMBRAPA-CPAF-AC, Boletim de pesquisa, 9).

D’Oliveira, M.V.N., Reutebuch, S.E., McGaughey, R.J., Andersen, H.E., 2012. Estimating forest biomass and identifying low-intensity logging areas using airborne scanning lidar in Antimary State Forest, Acre State, Western Brazilian Amazon. Remote Sens. Environ. 124, 479-491.

Dahle, G.A., Grabosky, J.C., 2009. Review of literature on the function and allometric relationships of tree stems and branches. Arboricult. Urban For. Champaign 35 (6), 311-320.

Dash, J.P., Marshall, H.M., Rawley, B., 2015. Methods for estimating multivariate stand yields and errors using k-NN and aerial laser scanning. Forestry, Oxford 88 (2), 237-247.

Detto, M., Asner, G.P., Muller-Landau, H.C., Sonnentag, O., 2015. Spatial variability in tropical forest leaf area density from multireturn lidar and modeling. J. Geophys. Res. Biogeosci. 120 (2), 294-309.

Drake, J.B., Dubayah, R.O., Clark, D.B., Knox, R.G., Blair, J.B., Hofton, M.A., Chazdon, R.L., Weishampel, J.F., Prince, S., 2002. Estimation of tropical forest structural characteristics using large-footprint lidar. Remote Sens. Environ. 79 (2-3), 305-319.

Fedrigo, M., Newnham, G.J., Coops, N.C., Culvenor, D.S., Bolton, D.K., Nitschke, C.R., 2018. Predicting temperate forest stand types using only structural profiles from discrete return airborne lidar. ISPRS J. Photogramm. Remote Sens. 136, 106-119.

Ferraz, A., Saatchi, S., Mallet, C., Meyer, V., 2016. Lidar detection of individual tree size in tropical forests. Remote Sens. Environ. 183, 318-333.

Figueiredo, E.O. 2014. Modelagem biométrica para arvores individuais a partir do Lidar em área de manejo de precisão em florestas tropicais na Amazônia Ocidental, p. 86 Tese (Doutorado em Ciências de Florestas Tropicais) - Programa de Pós-Graduação em Ciências de Florestas Tropicais - Instituto Nacional de Pesquisas da Amazônia INPA, Manaus/AM.

Figueiredo, S.M. de M., Venticinque, E.M., Figueiredo, E.O., Ferreira, E.J.L., 2015 Predição da distribuição de espécies florestais usando variáveis topográficas e de índice de vegetação no leste do Acre, Brasil. Acta Amazonica 45 (2), 167-174.

Garabedian, J.E., Moorman, C.E., Nils Peterson, M., Kilgo, J.C., 2017. Use of LiDAR to define habitat thresholds for forest bird conservation. For. Ecol. Manage. 399, 24-36.

Gorgens, E.B., Rodriguez, L.C.E., da Silva, A.G.P., Silva, C.A., 2015. Identificação de árvores individuais a partir de levantamentos laser aerotransportado por meio de janela inversa. Cerne 21 (1), 91-96.

Hansen, A.J., Phillips, L.B., Dubayah, R., Goetz, S., Hofton, M., 2014. Regional-scale application of lidar: Variation in forest canopy structure across the southeastern US. For. Ecol. Manage. 329, 214-226.

Hawbaker, T.J., Keuler, N.S., Leask, A.A., Gobakken, T., Contrucci, K., Radeloff, V.C., 2009. Improved estimates of forest vegetation structure and biomass with a LiDARoptimized sampling design. J. Geophys. Res. Biogeosci. 114 (3), 1-11.

Heurich, M., Thoma, F., 2008. Estimation of forestry stand parameters using laser scanning data in temperate, structurally rich natural European beech (Fagus sylvatica) and Norway spruce (Picea abies) forests. Forestry 645-661.

IBGE - Instituto Brasileiro de Geografia e Estatística, 2012. Manual Técnico da Vegetação Brasileira. 2a edição revista e ampliada. Sistema Fitogeográfico. Inventário das Formações Florestais e Campestres. Técnicas e Manejo de Coleções Botânicas. Procedimentos para Mapeamentos. Rio de Janeiro, RJ - Brasil. p. 271.

Jaskierniak, D., Lane, P.N.J., Robinson, A., Lucifer, A., 2011. Extracting LiDAR indices to characterise multilayered forest structure using mixture distribution functions. Remote Sens. Environ. 115 (2), 573-585.

Junttila, V., Finley, A.O., Bradford, J.B., Kauranne, T., 2013. Strategies for minimizing sample size for use in airborne LiDAR-based forest inventory. For. Ecol. Manage. 292, 75-85.

Kangas, A., Maltamo, M., 2006. Forest Inventory, Methodology and Applications. Springer, Dordrecht.

Kassambara, A., Mundt, F., 2017. . Factoextra: Extract and Visualize the Results of Multivariate Data Analysis. 
Kennel, P., Tramon, M., Barbier, N., Vincent, G., 2013. Canopy height model character istics derived from airbone laser scanning and its effectiveness in discriminating various tropical moist forest types. Int. J. Remote Sens. 34 (24), 8917-8935.

Lefsky, M.A., Harding, D., Cohen, W.B., Parker, G., Shugart, H.H., 1999a. Surface Lidar remote sensing of basal area and biomass in deciduous forests of eastern Maryland, USA. Remote Sens. Environ. 67, 83-98.

Lefsky, M.A., Cohen, W.B., Acker, S.A., Parker, G.G., Spies, T.A., Harding, D., 1999b. Lidar remote sensing of the canopy structure and biophysical properties of Douglasfir western hemlock forests. Remote Sens. Environ. 70 (3), 339-361.

Lefsky, M.A., Cohen, W.B., Parker, G.G., Harding, D.J., 2002. Lidar remote sensing for ecosystems studies. BioOne Res. Evol. 52 (1), 19-30.

Lu, D., Mausel, P., Brondízio, E., Moran, E., 2003. Classification of successional forest stages in the Brazilian Amazon basin. For. Ecol. Manage. 181 (3), 301-312.

Lu, D., 2005. Integration of vegetation inventory data and Landsat TM image for vegetation classification in the western Brazilian Amazon. For. Ecol. Manage. 213, 369-383.

MacArthur, R.H., Horn, H.S., 1969. Foliage profle by vertical measurements. Ecology 50, 802-804. https://doi.org/10.2307/1933693.

Mäkelä, A., Valentine, H.T., 2006. Crown ratio influences allometric scaling in trees. Ecology 87, 2967-2972.

Maltamo, M., Bollandas, O.M., Næsset, E., Gobakken, T., Packalén, P., 2011. Different plot selection strategies for field training data in ALS-assisted forest inventory. Forestry 84, 23-31.

Maltamo, M., Mehtätalo, L., Valbuena, R., Vauhkonen, J., Packalen, P., 2018. Airborne laser scanning for tree diameter distribution modelling: a comparison of modelling alternatives in a tropical single-species plantation. Forestry 91, 121-131.

Manzanera, J.A., García-Abril, A., Pascual, C., Tejera, R., Martín-Fernández, S., Tokola, T., Valbuena, R., 2016. Fusion of airborne lidar and multispectral sensors reveals synergic capabilities in forest structure characterization. GISci. Remote Sens. 53 (6), 723-738.

Marvin, D.C., Asner, G.P., Knapp, D.E., Anderson, C.B., Martin, R.E., Sinca, F., Tupayachi, R., 2014. Amazonian landscapes and the bias in field studies of forest structure and biomass. Proc. Natl. Acad. Sci. 111 (48), E5224-E5232.

Mascaro, J., Detto, M., Asner, G.P., Muller-Landau, H.C., 2011. Evaluating uncertainty in mapping forest carbon with airborne LiDAR. Remote Sens. Environ. 115 (12), 3770-3774.

Mauro, F., Molina, I., García-Abril, A., Valbuena, R., Ayuga-Téllez, E., 2016. Remote sensing estimates and measures of uncertainty for forest variables at different aggregation levels. Environmetrics 27 (4), 225-238.

Mcroberts, R.E., Chen, Q., Walters, B.F., 2017. Multivariate inference for forest inventories using auxiliary airborne laser scanning data. For. Ecol. Manage. 401, 295-303.

McRoberts, R.E., Gobakken, T., Næsset, E., 2012. Post-stratified estimation of forest area and growing stock volume using lidar-based stratifications. Remote Sens. Environ. $125,157-166$.

Moerman, D.E., Estabrook, G.F., 2006. The botanist effect: counties with maximal species richness tend to be home to universities and botanists. J. Biogeogr. 33, 1969-1974.

Moran, C.J., Rowell, E.M., Seielstad, C.A., 2018. A data-driven framework to identify and compare forest structure classes using lidar. Remote Sens. Environ. 211, 13-166.

Næsset, E., Gobakken, T., 2008. Estimation of above- and below-ground biomass across regions of the boreal forest zone using airborne laser. Remote Sens. Environ. 112, 3079-3090.

Næsset, E., Bollandsas, O.M., Gobakken, T., Gregoire, T.G., Stahl, G., 2013. Model-assisted estimation of change in forest biomass over an 11 year period in a sample survey supported by airborne LiDAR : a case study with post-stratification to provide "activity data". Remote Sens. Environ. 128, 299-314.

Niemi, M.T., Vauhkonen, J., 2016. Extracting canopy surface texture from airborne laser scanning data for the supervised and unsupervised prediction of area-based forest characteristics. Remote Sens. 8, 1-21.

Nijland, W., Coops, N.C., McDonald, S.E., Nielsen, S.E., Bater, C.W., Stadt, J.J., 2015. Comparing patterns in forest stand structure following variable harvests using airborne laser scanning data. For. Ecol. Manage. 354, 272-280.

Palace, M.W., Sullivan, F.B., Ducey, M.J., Treuhaft, R.N., Herrick, C., Shimbo, J.Z., Silva, J.M., 2015. Estimating forest structure in a tropical forest using field measurements, a synthetic model and discrete return lidar data. Remote Sens. Environ. 161, 1-11.

Ponzoni, F.J., Shimabukuro, Y.E., Kuplich, T.M., 2012. Sensoriamento remoto da vegetação, 2. ed. Oficina de Textos, São Paulo.

Qi, W., Lee, S., Hancock, S., Luthcke, S., Tang, H., Armston, J., Dubayah, R., 2019 Improved forest height estimation by fusion of simulated GEDI Lidar data and TanDEM-X InSAR data. Remote Sens. Environ. 221, 621-634. https://doi.org/10 1016/j.rse.2018.11.035.
R Core Team, 2017. R: A Language and Environment for Statistical Computing. R Found. Stat. Comput. Vienna, Austria. URL http//www.R-project.org/. R Foundation for Statistical Computing.

R Core Team, 2018. R: A Language and Environment for Statistical Computing Vienna, Austria.

Rodrigues, T.E., Silva, J.M.L. da, Cordeiro, D.G.A., Gomes, T.C. de A., Cardoso Júnior, E. Q., 2001. Caracterização e classificação dos solos do campo experimental da Embrapa Acre, Rio Branco, Estado do Acre. Belém: Embrapa (Embrapa Amazônia Oriental, Série Documentos, n. 122).

Roussel, J.R., Auty, D., 2018. lidR: Airborne LiDAR Data Manipulation and Visualization for Forestry Applications.

Sanz, B., Malinen, J., Leppänen, V., Valbuena, R., Kauranne, T., Tokola, T., 2018. Valuation of growing stock by multisource GIS data, stem quality database and bucking simulation. Can. J. For. Res. 48 (8), 888-897.

Silva, A.G.P., Görgens, E.B., Campoe, O.C., Alvares, C.A., Stape, J.L., Rodriguez, L.C.E., 2015. Assessing biomass based on canopy height profiles using airborne laser scanning data in eucalypt plantations. Sci. Agric. 72, 504-512.

Silva, C.A., Hudak, A.T., Vierling, L.A., Loudermilk, E.L., Brien, J.J., Hiers, J.K., Jack, S.B., Benecke, C.G., Lee, H., Falkowski, M.J., Khosravipour, A., 2016. Imputation of individual longleaf pine (Pinus palustris Mill.) tree attributes from field and LiDAR data. Can. J. Remote Sens. 42, 554-573.

Silva, C.A., Saatchi, S., Garcia, M., Labrière, N., Klauberg, C., Ferraz, A., Meyer, V., Jeffery, K.J., Abernethy, K., White, L., Zhao, K., Hudak, A.T., 2018. Comparison of small- and large-footprint lidar characterization of tropical forest aboveground structure and biomass: a case study from central Gabon. IEEE J. Sel. Top. Appl. Earth Obs. Remote Sens. 1-15.

Stark, S.C., Leitold, V., Wu, J.L., Hunter, M.O., de Castilho, C.V., Costa, F.R.C., McMahon, S.M., Parker, G.G., Shimabukuro, M.T., Takako, M., Lefsky, M.A., Keller, M., Alves, L.F., Schietti, J., Shimabukuro, Y.E., Brandão, D.O., Woodcock, T.K., Higuchi, N., de Camargo, P.B., de Oliveira, R.C., Saleska, S.R., 2012. Amazon forest carbon dynamics predicted by profiles of canopy leaf area and light environment. Ecol. Lett. Montpellier 15 (12), 1406-1414.

Stark, S.C., Enquist, B.J., Saleska, S.R., Leitold, V., Schietti, J., Longo, M., Alves, L.A., Camargo, P.B., Oliveira, R.C., 2015. Linking canopy leaf area and light environments with tree size distributions to explain Amazon forest demography. Ecol. Lett. 18 (7), 636-645.

Sullivan, F.B., Ducey, M.J., Orwig, D.A., Cook, B., Palace, M.W., 2017. Comparison of lidar- and allometry-derived canopy height models in an eastern deciduous forest. For. Ecol. Manage. 406, 83-94.

Tang, H., Dubayah, R., 2017. Seasonal variations of canopy structure in Amazon. Proc. Natl. Acad. Sci. U.S.A. 114 (10), 2640-2644.

Tipton, E., 2013. Stratified sampling using cluster analysis: a sample selection strategy for improved generalizations from experiments. Eval. Rev. 37 (2), 109-139.

Torresan, C., Corona, P., Scrinzi, G., Marsal, J.V., 2016. Using classification trees to predict forest structure types from LiDAR data. Ann. For. Res. 59 (2), 281-298.

Trimble, G., Geo, T. W., 2014. SCOP + + Manual for Version 5.5 and Higher.

Turner, D.P., Cohen, W.B., Kennedy, R.E., Fassnacht, K.S., Briggs, J.M., 1999. Relationships between leaf area index and Landsat TM spectral vegetation indices across three temperate zone sites. Remote Sens. Environ. 70 (52-68), 1999.

Valbuena, R., Packalen, P., García-Abril, A., Mehtätalo, L., Maltamo, M., 2013. Characterizing forest structural types and shelterwood dynamics from lorenz-based indicators predicted by airborne laser scanning. Can. J. For. Res. 43, 1063-1074.

Valbuena, R., Maltamo, M., Packalen, P., 2016. Classification of multi-layered forest development classes from low-density national airborne lidar datasets. Forestry 89, 392-1341.

Valbuena, R., Maltamo, M., Mehtätalo, L., Packalen, P., 2017. Key structural features of boreal forests may be detected directly using L-moments from airborne lidar data. Remote Sens. Environ. 194, 437-446.

Vastaranta, M., 2012. Forest Mapping and Monitoring Using Active 3D Remote Sensing. 45 f. 2012. Dissertationes Forestales 144 - Department of Forest Sciences, Faculty of Agriculture and Forestry, University of Helsinki, Finlândia.

Wulder, M.A., White, J.C., Nelson, R.F., Næsset, E., Ørka, H.O., Coops, N.C., Hilker, T., Bater, C.W., Gobakken, T., 2012. Lidar sampling for large-area forest characterization: a review. Remote Sens. Environ. 121, 196-209.

Wulder, M.A., Coops, N.C., Hudak, A.T., Morsdorf, F., Nelson, R., Newnham, G., Vastaranta, M., 2013. Status and prospects for LiDAR remote sensing of forested ecosystems. Can. J. Remote Sens. 39, S1-S5.

Yu, X., Hyyppä, J., Vastaranta, M., Holopainen, M., Viitala, R., 2011. Predicting individual tree attributes from airborne laser point clouds based on the random forests technique. ISPRS J. Photogramm. Remote Sens. 